\title{
Helicobacter pylori DNA in gallbladder tissue of patients with cholelithiasis and cholecystitis
}

\author{
Kuaybe Yucebilgili ${ }^{1}$, Tugba Mehmetoğlu${ }^{1}$, Zuhal Gucin², Barik A. Salih ${ }^{1}$ \\ ${ }^{1}$ Department of Biology, Faculty of Science and Literature, Fatih University, Turkey \\ ${ }^{2}$ Istanbul Teaching Hospital, Department of Pathology, Istanbul, Turkey
}

\begin{abstract}
Background: Earlier reports on the detection of H. pylori DNA in gallbladder tissue of patients with cholelithiasis and cholecystitis gave discordant results. Our aim was to detect the presence of $H$. pylori DNA and to determine whether a correlation can be established with the biliary diseases.

Methodology: The study included a total of 68 patients 20 to 79 years of age. Fifty-three of the participants were females, of whom 33 had cholelithiasis and 20 did not. Out of the 15 male patients, 8 were had cholelithiasis and 7 did not. Gallbladder tissue specimens were taken from all patients undergoing cholecystectomy and processed immediately for histology, culture and PCR.

Results: Histological examination revealed that $36(68 \%)$ of 53 females and $9(60 \%)$ of 15 males had cholecystitis. PCR results detected $H$. pylori DNA in $15(22 \%)$ of 68 samples but no bacteria were isolated in culture. The presence of few bacteria, the geographic distribution of H. pylori strains, and the bile milieu inhibitory effect might be some of the reasons for growth failure.

Conclusions: In this study although H. pylori DNA was detected by PCR in gallbladder tissue of patients with cholecystitis, a clinical correlation with biliary disease could not be established because several conditions were difficult to meet as discussed in the text.
\end{abstract}

Key words: Helicobacter pylori, cholelithiasis, cholecystitis, PCR

J Infect Dev Ctries 2009; 3(11):856-859.

(Received 17 July 2009 - Accepted 26 October 2009)

Copyright (C) 2009 Salih et al. This is an open-access article distributed under the Creative Commons Attribution License, which permits unrestricted use, distribution, and reproduction in any medium, provided the original work is properly cited.

\section{Introduction}

Helicobacter pylori, a Gram-negative bacterium that colonizes the human gastric epithelium, infects $50 \%$ of the world populations. It is the causative agent of peptic ulcer diseases and a major contributor to gastric cancer. Whether $H$. pylori participates in the pathogenesis of biliary diseases is a question that has been addressed by several investigators. The DNA of $H$. pylori has been identified in the bile, liver, and biliary epithelium of patients with hepatobiliary diseases $[1,2,3]$. In regard to the biliary diseases, in one study, $H$. pylori specific ureB DNA was detected in the gallbladder tissue of a Japanese patient with gallstone and cholecystitis [4]. Similarly Chen et al. [5] found $H$. pylori ureA and ureB DNA in $13.55 \%$ of the gallbladders of patients with cholecystitis. However, in a study evaluating the presence of $H$. pylori ureA DNA in the bile by nested PCR, Lin et al. [1] observed a negative result in four patients with biliary diseases. Queiroz et al. [6] were able to isolate $H$. pylori strain from the liver of a Brazilian patient with cirrhosis, which indicates that
H. pylori may be viable in the human liver. In studies that included a larger number of patients, discordant results have also been observed. A study from Yugoslavia [7] revealed that the presence of $H$. pylori-specific DNA in the bile was associated with biliary tract carcinoma but no association was seen between patients with gallstone and those without biliary disease. Other studies from Germany [8] and Mexico [9] failed to detect the presence of DNA of Helicobacter spp. in bile or gallbladder tissue from patients with biliary diseases. Furthermore, DNA of Campylobacter (rather than that of Helicobacter) was detected in the bile and biliary epithelium of Japanese patients with cholelithiasis [10]. Regional differences may contribute to these discordant results. Furthermore, it has also been emphasized that most of these studies involved few control patients or no control group at all. The objectives of this study were to detect the presence of $H$. pylori DNA in gallbladder tissue, attempt to isolate the bacterium from these tissues, and to determine its association with the biliary diseases. 
Table 1. Patient distribution in regards to gender and cholelithiasis

\begin{tabular}{cccc} 
Patient & $\begin{array}{c}\text { with } \\
\text { cholelithiasis }\end{array}$ & $\begin{array}{c}\text { without } \\
\text { cholelithiasis }\end{array}$ & Total \\
Female & 33 & 20 & 53 \\
Male & 8 & 7 & 15 \\
Total & 41 & 27 & 68 \\
\hline
\end{tabular}

\section{Materials and methods}

Patients

A total of 68 patients aged 20 to 79 years (average 52 years) attending the Istanbul Teaching hospital on a consecutive basis were included in this study. Fifty-three of the patients were females. Among the 53 females, 33 had cholelithiasis and 20 did not. Of the 15 male participants, 8 were had cholelithiasis and 7 did not. Only patients who received no antimicrobial drugs for four weeks before surgery were included. Gallbladder tissue specimens (neck and body) were obtained from each patient undergoing cholecystectomy and then processed immediately for histology and culture or frozen at $-20^{\circ} \mathrm{C}$ for DNA extraction. An informed written consent was obtained from each patient and the study was approved by the hospital's ethical committee. The GCP principles were followed during the different stages of this study.

\section{Histology}

Gallbladder tissue specimens for histology were fixed immediately in $10 \%$ buffered formalin and then embedded in paraffin wax. Thin sections were stained with hematoxylin and eosin for histological analysis. The presence of cholecystitis was diagnosed by the presence of mononuclear and polymorphonuclear leukocytes in lamina propria, crypts of epithelium that results from fusion of the mucosal folds, and the presence of sinuses [11].

\section{Microbiology}

The gallbladder tissue specimens for culture placed in $0.5 \mathrm{ml}$ of PBS buffer were transported immediately to the lab under cold conditions. The samples were homogenized in an Ultratrax homogenizer (Germany) and inoculated onto freshly prepared Colombia agar medium (Oxoid, UK) with $5 \%$ horse blood. Plates were incubated under microaerophilic conditions at $37^{\circ} \mathrm{C}$ for seven days. In addition, four biopsy specimens were also obtained from the antral part of the stomach of four patients undergoing upper gastroendoscopy to be used as a control for the isolation of $H$. pylori. The specimens were handled in a similar way to those of the gallbladder specimens.

\section{DNA isolation}

Gallbladder tissue DNA was extracted with a QIAamp DNA Mini kit (Qiagen $\mathrm{GmbH}$, Hilden, Germany) according to the manufacturer's instructions.

\section{PCR}

PCR amplification of the 16S rRNA in gallbladder tissue specimens was done using the forward primer 16S-rRNA.F 5, TAAGAGATCAGCCTATATGTCC 3 ' and the reverse primer 16S-rRNA.R 5' TCCCACGCTTTAAGCGCAAT 3' [12]. The same primers were also used to amplify the DNA from the antral specimens. The setup was a denaturation at $94^{\circ} \mathrm{C}$ for 30 seconds, annealing at $56^{\circ} \mathrm{C}$ for 30 seconds, extension at $72^{\circ} \mathrm{C}$ for 1 minute, for 40 cycles and a final extension step at $72^{\circ} \mathrm{C}$ for 5 minutes using the thermal cycler (Techne, UK).

Statistical analysis

Data were analyzed with a statistical software package, version 10 (SPSS Inc., Chicago, Ill.). A $P$ value of $<0.05$ was set as significant.

\section{Results}

The distribution of patients according to their gender and the biliary diseases is shown in table 1 . The attempt to isolate $H$. pylori from gallbladder tissue specimens was negative. No $H$. pylori was grown in culture, even though plates were incubated for up to 14 days. However, we were able to isolate $H$. pylori in culture from three out of the four stomach antral specimens. Histological examination of tissue specimens revealed that $36(68 \%)$ of 53 females and $9(60 \%)$ of 15 males had cholecystitis. Thin sections of these tissues showed inflammatory cell infiltration, degenerative changes, and necrosis in the region where $H$. pylori DNA was present or not. However, the severity of the inflammatory changes were more obvious in $H$. pylori positive samples $(P=$ $0.05)$. We were able to amplify the $H$. pylori $16 \mathrm{~S}$ rRNA gene (amplicon size of $625 \mathrm{bp}$ ) even though the gallbladder tissue is not the favoured site for $H$. pylori as is that of the antral region of the stomach. PCR results showed that $H$. pylori DNA was detected in $15(22 \%)$ of 68 samples, of these 2 samples were 
Figure 1. PCR results showing positive bands of $H$. pylori DNA in gallbladder tissues (lane 1,2,3,4,5). Lane 6 and 7 were negative. M: molecular marker.

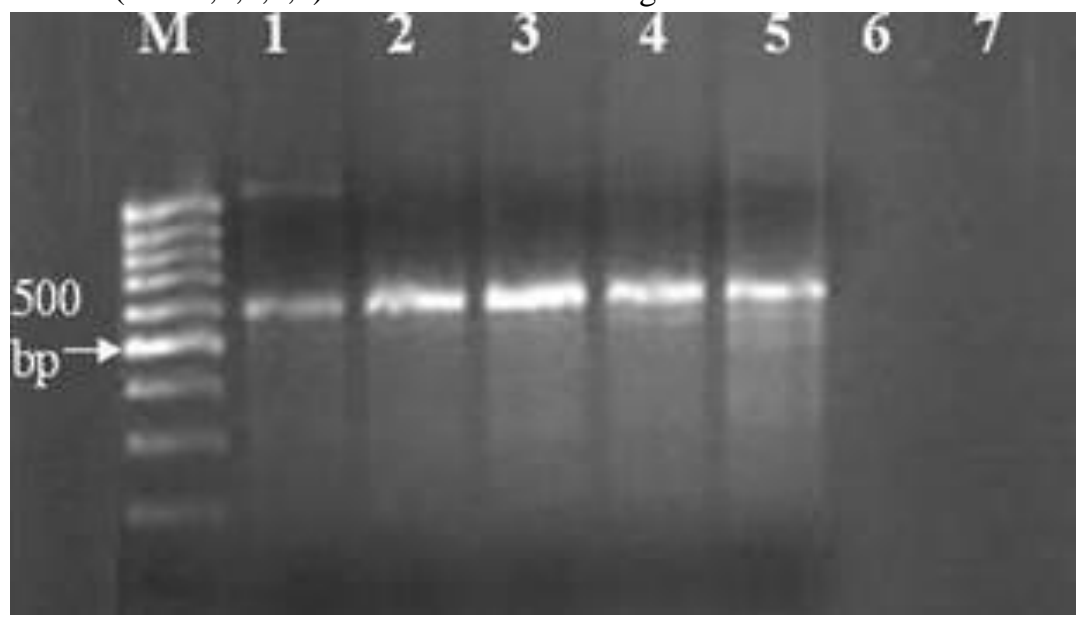

from patients who also had cholelithiasis. We also detected $H$. pylori DNA in the 3 antral biopsy specimens by PCR which further confirmed the amplification process.

\section{Discussion}

The presence of $H$. pylori DNA in the gallbladder epithelium of patients with cholelithiasis and cholecystitis has been reported. However, the results were conflicting and some investigators detected the presence of $H$. pylori DNA [11] while others did not $[8,13]$. This phenomenon might be attributed to the small number of subjects studied, differences in the studied populations, the geographic distribution of $H$. pylori, and the difficulty in obtaining a healthy control group.

The distribution of $H$. pylori in gallbladder tissue is well known to be scarce, a fact that makes the localization and finding of this bacteria a difficult task. Our findings were consistent in terms of the amplified PCR products of $H$. pylori DNA obtained from different gallbladder samples. We were able to detect $H$. pylori DNA in $22 \%$ of the samples of patients with cholelithiasis and cholecystitis; however, whether it has a role in pathogenesis is still questionable. On the other hand, samples that turned negative might be the result of the presence of few bacteria, inhibitory effect of the biliary milieu, or needed certain requirements that have to be adopted.

In one recent study Chen et al. [5] indicated that H. pylori exist in the gallbladders of patients with chronic cholecystitis, and in another they showed [14] that $H$. pylori infection may be related to cholecystitis. While Silva et al. [11] reported earlier that even though their findings pointed toward a real association between $H$. pylori infection and cholecystitis, they did not rule out the possibility that H. pylori colonized a previously damaged epithelium. Stathopoulos et al. [15] have investigated the relation of gallbladder function and $H$. pylori infection to gastric mucosa inflammation in patients with symptomatic gallstones prior to cholecystectomy and reported that the gallbladder function is not related to the degree of gastritis. So it appears that several important factors and requirements have to be met in order to establish a definitive association between the presence of $H$. pylori and biliary diseases. In addition, we were unable to isolate the bacterium in culture as has been reported by other investigators in a previous study [11]. As suggested earlier, the failure to do so could be due to the bacterial conversion from viable helicals to non-viable coccoids in an adverse bile-rich environment. This study demonstrated the existence of $H$. pylori DNA in gallbladder tissue; hence future studies are needed to investigate the exact role of this bacterium in this organ.

In conclusion, in this study although we have detected $H$. pylori DNA by PCR in gallbladder tissue of patients with cholecystitis, a clinical correlation with the biliary disease could not be established because several conditions that are difficult meet limited the investigation. Further studies that include healthy control subjects, patients with biliary diseases that also harbor $H$. pylori in their stomachs, isolation of the bacterium from both locations, and molecular analysis of the isolated strains are required in order to establish a significant correlation. 


\section{Acknowledgement}

The study was supported by a grant from Fatih University (\#P50030501).

\section{References}

1. Lin TT, Yeh CT, Wu CS, Liaw YF (1995) Detection and partial sequence analysis of Helicobacter pylori DNA in the bile samples. Dig Dis Sci 40: 2214-2219.

2. Nilsson HO, Mulchandani R, Tranberg KG, Taneera J, Caastedal M, Glatz E, Olsson R, Wadstrom T (2001) Helicobacter species identified in liver from patients with cholangiocarcinoma and hepatocellular carcinoma. Gastroenterol 120: 323-324.

3. Nilsson HO, Taneera J, Caastedal M, Glatz E, Olsson R, Wadstrom $\mathrm{T}$ (2000) Identification of Helicobacter pylori and other Helicobacter species by PCR, hybridization, and partial DNA sequencing in human liver samples from patients with primary sclerosing cholangitis or primary biliary cirrhosis. J Clin Microbiol 38: 1072-1076.

4. Kawaguchi M, Saito T, Ohno H, Midorikawa S, Sanji T, Handa Y, Morita S, Yoshida H, Tsurui M, Misaka R, Hirota T, Saito M, Minami K (1996) Bacteria closely resembling Helicobacter pylori detected immunohistologically and genetically in resected gallbladder mucosa. J Gastroenterol 31: 294-298.

5. Chen DF, Hu L, Yi P, Liu WW, Fang DC, Cao H (2007) $H$. pylori exist in the gallbladder mucosa of patients with chronic cholecystitis. World J Gastroenterol 13: 1608-1611.

6. Queiroz DMM, Santos A, Oliveira AG, Rocha GA, Moura SB, Camargo ERS, Valle PR, Bicalho LAF, Dani R (2001) Isolation of a Helicobacter strain from the human liver. Gastroenterol 121: 1023-1024. Erratum, 122: 250, 2002.

7. Bulajic M, Maisonneuve P, Schneider-Brachert W, Muller P, Reischl U, Stimec B, Lehn N, Lowenfels AB, Lohr M (2002) Helicobacter pylori and the risk of benign and malignant biliary tract disease. Cancer 95: 1946-1953.

8. Rudi J, Rudy A, Maiwald M, Stremmel W (1999) Helicobacter sp. Are not detectable in bile from German patients with biliary disease. Gastroenterol 116: 1016-1017.

9. Mendez-Sanchez N, Pichardo R, Gonzalez J, Sanchez H, Moreno M, Barquera F, Estevez HO, Uribe M (2001) Lack of association between Helicobacter sp. colonization and gallstone disease. J Clin Gastroenterol 32: 138-141.

10. Harada K, Ozaki S, Kono N, Tsuneyama K, Katayanagi K, Hiramatsu K, Nakanuma Y (2001) Frequent molecular identification of Campylobacter but not Helicobacter genus in bile and biliary epithelium in hepatolithiasis. J Pathol 193: 218-223.

11. Silva CP, Pereira-Lima JC, Oliveira AG, Guerra JB, Marques DL, Sarmanho L, Cabral MMDA, Queiroz DMM (2003) Association of the presence of Helicobacter in gallbladder tissue with cholelithiasis and cholecystitis. J Clin Microbiol 41: 5615-5618.

12. Tiwari SK, Khan AA, Ibrahim M, Habeeb MA, Habibullah CM (2006) Helicobacter pylori and other Helicobacter species DNA in human bile samples from patients with various hepato-biliary diseases. World J Gastroenterol 12: 2181-2186.

13. Mendez-Sanchez N, Pichardo R, Gonzalez J, Sanchez H, Moreno M, Barquera F, Estevez HO, Uribe M (2001) Lack of association between Helicobacter sp colonization and gallstone disease. J Clin Gastroenterol 32: 138-141.

14. Chen DF, Hu L, Yi P, Liu WW, Fang DC, Cao H (2007) $H$. pylori are associated with chronic cholecystitis. World $\mathrm{J}$ Gastroenterol 13: 1119-1122.

15. Stathopoulos P, Zundt B, Spelsberg FW, Kolligs L, Diebold J, Goke B, Jungst D (2006) Relation of gallbladder function and Helicobacter pylori infection to gastric mucosa inflammation in patients with symptomatic cholecystolithiasis. Digestion 73: 69-74.

Conflict of Interest: No conflict of interest is declared.

\section{Corresponding Author}

Barik A. Salih

Department of Biology

Faculty of Science and Literature

Fatih University

Istanbul, Turkey

Tel: +90-212-8663300

Fax: +90-212-8663402

Email: basalih@fatih.edu.tr 